\title{
Impressions of Early Iowa: \\ Pioneer Letters and Reminiscences
}

\section{ROBERTA. M c COW N}

"Iowa is full of strangers looking at the soil from all parts of the world and I do not suppose that there ever was a state with the exception of California that there is such a tide of immigration to." 1 Permanent settlers began to come into what is now the state of Iowa in 1833, and by 1836 the population was put at 10,531 . On July 4,1838 , the Territory of Iowa was created, and the population figure was 22,859 . By 1846 the number of people stood at 96,088 , and Iowa became a state. However, pioneers had only started to arrive, for by 1850 Iowa census figures placed the population at 192,204 and in 1859, on the eve of the Civil War, at $633,547 .^{2}$ The West seems to have been won very quickly.

What were the reactions of these first Iowans to their new home? Did some come with a sense of wonderment and visions of the future, others with slight trepidation? Did they question whether they could make a living, stay out of debt, avoid accidents and sickness, and stand up to the rigors of frontier life? ${ }^{3}$ Some of those early "Hawkeyes"

1 N. H. H. Ward to Mrs. Bradley Bartholomew, June 18, 1854, Bartholomew Family Papers, The University of Iowa Libraries, Iowa City, Iowa. The Bartholomew Family Papers contain about 213 items of correspondence describing life in Iowa between 1850 and 1910 .

2 Iowa, Census Board, The Census Returns of the Different Counties of the State of Iowa, for 1859 . . . To Which Is Appended a Table Showing the Population of Iowa for Several Years Since 1836 (Des Moines: J. Tresdale, State Printer, 1859), p. 1.

3 Perhaps the best introduction to pioneer life in lowa can be found in a work of fiction by Herbert Quick, Vandemark's Folly (Indianapolis: The Bobbs-Merrill Co., 1922). This novel tells the story of how Jacob Teunis Vandemark comes to Monterey County, Iowa (Grundy County) from New York and settles on the prairie land and in a long life witnesses the changes going on about him. There seems to be no recent nonfiction work which covers the frontier period in Iowa very adequately. The standard view is contained in William J. Petersen, The Story of lowa, the Progress of An American State, Vol. 1 (New York: Lewis His- 
answered these questions in the letters that they sent back to their families in Ohio, Kentucky, Pennsylvania and New York. Fortunately, a few pioneer letters have survived and are now in the Special Collections Department of The University of Iowa Libraries.

To perhaps most of the first pioneers, Iowa was a land of promise and opportunity. One woman expressed her feelings about her new home in an unpunctuated letter: "We have some beautiful weather now I can hardly stay in the house Winterset is improving I cannot tell how many houses are going up now their will be over a hundred go up this summer this town is going to be one of them someday." 4 Another early settler expressed this view:

About three weeks since I took a horse travelled up to the Indian
boundary line about fifty miles west on to the Des Moines river fol-
lowed it to its mouth \& so back home-the weather was fine \& this
prairie country is seen to its greatest advantage-I do not believe there
is a handsomer river in the far west than the Des Moines or a better
country than borders it. ${ }^{5}$

Probably a good many early pioneers would have agreed with that assessment.

However, like people in every time and place, new surroundings gave some of those first Iowans a terrible heartsick feeling. After all, loved ones and familiar faces had been left far behind. Great effort had been expended in reaching their new home, and a family just couldn't pack up and go back again very easily. Often contact with relatives at home must have been cut off, for the settlers complained of poor mail service. Lost letters were not uncommon. There were, of course, many other worries, such as lack of adequate medical care, schools and familiar church services. One homesick fellow wrote to his brother:

You sent questions as to wheather whether whe are a coming back. I do not know what to say I would a grate deele rather live in Indiana than to live here but wheather I could do as well thar as here is the question it has ben my calculation for somtime to com back next spring

torical Publishing Co., 1952), pp. 352-381. Two excellent, but highly specialized works which deal with the pioneer period are Allan G. Bogue, From Prairie to Corn Belt, Farming on the Illinois and Iowa Prairies in the Nineteenth Century (Chicago: The University of Chicago Press, 1963) and Robert P. Swierenga. Pioneers and Profits: Land Speculation on the lowa Frontier (Ames: The Iowa State University Press, 1968).

4 Ellen Ward to Mrs. Bradley Bartholomew, April 20, 1856, Bartholomew Family Papers.

5 Henry Eno to Stephen Eno, July 12, 1837, Henry Eno Letters, The University of Iowa Libraries, Iowa City, Iowa. The Henry Eno Letters contain 51 items. mostly letters to Eno's father, Stephen Eno, concerning experiences in Penn Yan. N.Y.; Fort Madison, Iowa; and California. 
now as I said in my last letter that if you will buy a good farm in some good place whare I can send my children to school and handy to meeting I will com and liv on it and rent it from you and make it profitable to you as thare is not much chanc of scooling them here and it as much as I can do for them I want to giv them a chance to go to scool. ${ }^{6}$

Others may have had the same sad feelings after their arrival in Iowa. Yet, new friends were made, new experiences were shared, log houses were quickly raised with the help of other members of the community, and soon schools and churches made their appearance.

One early Iowa pioneer was Henry Eno, the first lawyer to make his home in Fort Madison. Eno was born in 1798 in Dutchess County, New York. He followed the profession of his father, Stephen Eno, but decided not to remain at home. He first settled in Penn Yan, New York, in the western part of that state. Then in late 1836 he moved to Fort Madison with hopes that he could continue his legal practice but also engage in land speculation. During his first summer in Fort Madison, Eno wrote to his father that "we celebrated the 4th of July in very good style for a new \& wild Country, about 500 persons came in to hear me give them a Western speech and we all sat down to a dinner in the open air." $\mathrm{A}$ later source reports that Henry Eno read the Declaration of Independence and that another lawyer had delivered the main oration, but Eno can probably be forgiven for inflating his importance in a letter to his father. ${ }^{8}$ The traditional Fourth of July festivities must have made many of those pioneers feel a bit more at home and given them a chance to relax, talk with their new neighbors and eat a picnic dinner. One interesting sidelight of that particular day was that Chief Black Hawk made his last public appearance as guest of honor at the dinner. ${ }^{9}$

While in Fort Madison, Henry Eno married the daughter of General John A. Knapp, the second settler and one of the founders of Fort Madison. ${ }^{10}$ Eno and his bride found that life on the frontier did have some compensations. In a letter to his brother he reported: "I can buy a saddle of venison weighing $40 \mathrm{lbs}$ or upwards for one dollarprairie chickens can be had in great abundance for the shooting."11 Still, there were problems that were difficult to cope with. In 1838

6 William Bartholomew to Dr. Bradley Bartholomew, January 31, 1852, Bartholomew Family Papers.

7 Henry Eno to Stephen Eno, July 12, 1837, Henry Eno Letters.

8 Writers' Program, Iowa, Lee County History, Iowa (Keokuk, 1942), p. 75.

$\theta$ Ibid., p. 76.

10 Henry E. Knapp, "General John H. Knapp, the First Permanent Settler of Fort Madison, Iowa" Annals of Iowa, X, 3d Series (October, 1911), pp. 161-165.

11 Henry Eno to William Eno, December 28, 1848, Henry Eno Letters. 
Eno wrote his father: "there has been more sickness than I have known during all the time I have been in the Country-the hot weather and exuberant growth of vegitation \& the river also being now very low are the probable causes."12

In 1848 Henry Eno developed a new sort of sickness that was spreading throughout the land, California gold fever. Eno had found neither his law practice nor his land speculations very lucrative. He complained: "The profession of law is overdone here, lawyers swarm like the locusts of Egypt-there is over 40 in this county \& not one who makes a living by his profession."13 Always something of a dreamer and an optimist, he left for California in 1848. He went as a gold seeker, but after arrival was employed as a newspaper editor, minor politician, lawyer, judge and businessman. He traveled in the mining districts of the Mojave Desert and Death Valley and participated in the 1868-9 silver rush at White Pine, Nevada. Eventually he went home to New York to spend his last years. ${ }^{14}$

Frontier life itself was one of the attractions of Iowa. One of the most enthusiastic early pioneers was William Harvey Ingham, father of Harvey Ingham, former editor of the Des Moines Register and Tribune. William Ingham arrived in Cedar Rapids in 1851 where he lived until 1854 when he moved to Algona in Kossuth County. He loved the outdoors and the adventure of a new land. Iowa winters were something to look forward to because of sleigh riding and snowshoeing. In 1854 he wrote to his brother Erastus back in upstate New York: "Snow has not been over three inches deep at any one time hardly enough for sleighing-although we have the best place for riding this side of no where on the river as we can go on the ice to our hearts content." 15 In the same letter Ingham describes one of his outings:

As you are something of a fisherman I shall have to tell you what was did in two days a couple of weeks ago-there was at least 200 men \& boys with spears on the ice killing fish-all getting as many as they could drag and some a wagon load-it went beyond anything I ever saw

12 Henry Eno to Stephen Eno, September 15, 1838, Henry Eno Letters.

13 Henry Eno to William Eno, December 28, 1848, Henry Eno Letters.

14 For an introduction to Eno's life and an edition of his California letters see W. Turrentine Jackson, ed., Twenty Years on the Pacific Slope, Letters of Henry Eno from California and Nevada, 1848-1871 (New Haven: Yale University Press, 1965).

15 William Ingham to Erastus Ingham, February 13, 1854, Ingham Family Letters, The University of Iowa Libraries, Iowa City, Iowa. The Ingham Family Letters consist of six letters given to the Library by a grandniece of William Ingham, Miss Alice A. Guller of Hamilton, New York. 
-the ice was covered with blood for some ways above the dam the fished weighed from five to thirty lbs each. ${ }^{16}$

One wonders if Ingham's brother believed that story.

Later on, Ingham became captain of Company A of the Northern Border Brigade, which was organized in 1862 after a Sioux Indian attack in the New Ulm, Minnesota area had killed over 600 persons. A chain of forts was constructed from the Big Sioux River on the western border eastward to Clear Lake to protect the settlers of northern Iowa. ${ }^{17}$ Then in 1870 he and a partner organized the first bank in Algona. Sitting at his desk on a long afternoon, Mr. Ingham must have thought often of Algona in the early days:

Deer are very plenty within $1 / 2$ mile of the cabin \& very frequently not more than 20 rods distant - 10 have found their final resting place on the cabin roof. I can kill one or two almost every time I go out. Elk are not very plenty have scen only 2 gangs since I returned gave one a chase with fine prospects ahead until my nag changed right about face \& I made a fine impression in the snow-my horse left me 12 miles in the prairie to walk in which made it decidedelly interestinghad two buffalo chases one herd of $14 \&$ one of about 80 . Captured one \& wounded three others. They are fine game but difficult to kill.18

Ingham is remembered as the first man to shoot an elk and the only man to shoot a buffalo in Kossuth County. ${ }^{19}$

Even before Ingham began chasing buffalo in western Iowa, the frontier era was passing quickly in the eastern portion of the state. In 1843 a young lady in Big Grove Township, Johnson County, north of Iowa City, wrote to her brother and sister back in Ohio: "I went to School 3 monts last summer in Iowa Citty we have Singing School every Saturday night within 2 miles of us and a temperance meetings with in a miles of us." 20

A day at a rural school could be one of frolicsome fun, but also of stern discipline. James Peery Schell, pioneer Presbyterian clergyman

16 Ibid.

17 William H. Ingham, "The Iowa Northern Border Brigade of 1862-3," Annals of Iowa, V, 3d Series (October, 1902), pp. 481-523, and Harvey Ingham, The Northern Border Brigade, a Story of Military Beginnings (Des Moines? 1926?).

18 William Ingham to Erastus Ingham, December 2, 1855, Ingham Family Letters.

19 Florence Call Cowles, Early Algona, the Story of Our Pioneers, 1854-1874 (Des Moines: The Register and Tribune Co., 1929), pp. 69-70. See also William Harvey Ingham, Ten Years on the lowa Frontier; Pioneer Experiences of Wm. $H$. Ingham in the Fifties (n.p., n.d.).

20 Ruth Moore to her "Brother and Sister," February 2, 1843, Moore Family Papers, The University of Iowa Libraries, Iowa City, Iowa. The Moore Family Papers contain 10 letters dating from 1840 to 1884. 
in North Dakota and graduate of The University of Iowa, recalled one young teacher from the East: "For the larger pupils-boys especiallyseated on their long bench . . . when found forgetful for the moment of their duties as scholars, he would quietly step up from behind and slip from his pocket a spring clothespin and snap one or more on the ear of the unsuspecting youth." 21

Even before the Civil War, Iowa began to change in appearance. By the end of 1855 a railroad reached Iowa City. With the railroad came logs from the mill towns along the Mississippi, and frame houses began to take the place of log cabins. The sons of the first settlers formed military companies and went off to serve in the war. Except in the northwest part of the state, the pioneer period was drawing to a close by 1860 .

21 James Peery Schell, "Seen thru Memory's Windows or Seventy Years Beyond the Mississippi, An Autobiography" (Unpublished typescript), p. 69, in The James Peery Schell Papers, The University of Iowa Libraries, Iowa City, Iowa. The Schell Papers consist of three autobiographical manuscripts and one long letter to his children. Schell (1845-1932) was born on an Iowa farm between Iowa City and West Liberty. He was the author of In the Ojibway Country; a Story of Early Missions on the Minnesota Frontier (Walhalla, N.D.: C. H. Lee, 1911). Recently a portion of his memoirs dealing with the Civil War has been printed as $A$ Taste of Army Life (Iowa City: The Gordian Press, 1964). 